\title{
TENSIONES INTRAECLESIALES EN TORNO A LAS COFRADÍAS DE LA SEMANA SANTA DE HUELVA (1964-1975)
}

\author{
POR \\ JosÉ CARLOS MANCHA CASTRO ${ }^{1}$ \\ Universidad de Huelva
}

\section{RESUMEN}

Durante el primer franquismo, las procesiones de Semana Santa en Huelva fueron espacios socio-simbólicos instrumentalizados por los poderes políticos y eclesiásticos locales para representar y ritualizar unas narrativas e imaginarios que sirvieran para construir una legitimación sagrada y popular de la dictadura. Pero en las décadas de los sesenta y setenta, una parte de la Iglesia se desvinculó de ese proyecto compartido con el régimen, y la Semana Santa se convirtió en un escenario simbólico en el que se reflejaron conflictos intraeclesiales y sociopolíticos entre dos culturas políticas católicas. Este trabajo aborda una aproximación a la división eclesiástica y las tensiones expresadas a lo largo del segundo franquismo a propósito de la Semana Santa onubense, reflejo de la fractura entre poderes con la que concluiría el régimen franquista.

PALABRAS CLAVE: franquismo; Iglesia católica; cofradías; concilio Vaticano II; religiosidad popular.

\section{ECCLESIASTICAL TENSIONS AROUND CONFRATERNITIES OF HUELVA'S EASTER (1964-1975)}

\begin{abstract}
During early Francoism, processions of Huelva's Easter were socio-symbolic stages where the political and ecclesiastical authorities ritualized and represented narratives and imaginaries that served to construct a sacred and popular legitimacy of the dictatorship. But in the sixties and seventies, a part of the Catholic Church would dissociate itself from that project shared with Francoist regime. Easter became a symbolic stage of ecclesiastical and sociopolitical conflicts between two Catholic political cultures. This paper deals with an approach to ecclesiastical division and tensions expressed throughout the second Francoism around Huelva's Easter. These were a reflection of fracture which Francoist regime would end.
\end{abstract}

KEY WORDS: francoism; Catholic Church; confraternities; Second Vatican Council; popular religiosity.

CÓMO CITAR ESTE ARTículo / CITATION: Mancha Castro, José Carlos. 2020. «Tensiones intraeclesiales en torno a las cofradías de la Semana Santa de Huelva (1964-1975)». Hispania Sacra LXXII, 146: 605-619. https://doi.org/10.3989/hs.2020.045

\author{
Recibido/Received 21-02-2019 \\ Aceptado/Accepted 02-09-2019
}

\section{INTRODUCCIÓN}

A la altura de la Semana Santa de 1964, el pontificado de Pedro Cantero Cuadrado en la sede episcopal de Huelva iba camino de su final. Su nombramiento como arzobispo de Zaragoza significó la marcha del primero de los dos obispos

\footnotetext{
1 jose.mancha@pi.uhu.es / ORCID iD: https://orcid.org/0000-0003-0092-4417
}

diocesanos representantes de la Iglesia de Franco. ${ }^{2}$ Con su partida, comenzaría a desintegrarse uno de los propósitos fundamentales que habían hecho posible la materialización del proyecto de recatolización de la ciudad onubense durante todo el primer franquismo: utilizar la Semana Santa

2 Para Casanova Ruiz 2005, 237, la Iglesia de Franco era aquella que «se identificaba con él, que lo admiraba como Caudillo, como un enviado de Dios para restablecer la consustancialidad de la cultura tradicional española con la fe católica». 
y otras fiestas religiosas populares para la adhesión y legitimación social del nacionalcatolicismo en tanto ideología hegemónica entre las diferentes familias que componían el régimen, como espacios de exhibición pública de los diferentes grupos sociales, políticos e ideológicos coaligados en él y como festejos a través de los que ritualizar la dictadura, recordar su legitimidad sagrada, rememorar la victoria sobre los enemigos de Dios y de España y, sobre todo, celebrarla. Tras Cantero Cuadrado vendría José María García Lahiguera, otro obispo perteneciente a esa «lglesia que hablaba más de Franco que de Jesucristo", ${ }^{3}$ pero su pontificado sería breve y de transición. El verdadero cambio en la Iglesia onubense se experimentaría con la llegada del aperturista Rafael González Moralejo en $1969 .{ }^{4}$

A lo largo de ese intenso proceso de crisis eclesial que tuvo lugar desde la marcha de Cantero Cuadrado hasta el primer lustro del pontificado de González Moralejo, se vivió una historia de tensión y combate entre dos culturas políticas católicas, ${ }^{5}$ una representada por eclesiásticos significados por las ideas nacionalcatólicas integristas, tradicionalistas y contrarrevolucionarias y convencidos del papel político que debía jugar la jerarquía de la Iglesia española en las esferas de poder de la dictadura, frente a otros que representaban a la corriente aperturista-conciliar y defendían un cambio en la posición de la Iglesia en su relación con la comunidad política, la dictadura y el Estado. Las consecuencias de esa tensión se visibilizarían simbólicamente en la Semana Santa onubense, donde se observaba nítidamente la apropiación que de las procesiones religiosas populares habían hecho los poderes políticos y militares franquistas locales y esa curia preconciliar y reaccionaria desde la Guerra Civil y durante todo el primer franquismo. A propósito de las nuevas tesis del concilio Vaticano II, los curas aperturistas repudiarían ese tipo de prácticas rituales y combatirían las ideas de los otros.

Este artículo pretende analizar la división eclesiástica y las tensiones que se vivieron en las décadas de los sesenta y setenta a propósito de la Semana Santa y de su instrumentalización como fiesta para ritualizar la legitimidad de la dictadura, así como las causas y consecuencias de la ruptura de esa relación entre el poder político y el religioso, que heriría de muerte al régimen de Franco.

\section{ANTECEDENTES, MARCO TEÓRICO-METODOLÓGICO Y FUENTES}

El estudio de fiestas y rituales populares como mecanismos simbólicos de legitimación de regímenes políticos modernos es una temática incipiente, aunque aún marginal, en la historiografía española contemporánea. En los últimos años, diversos han sido los trabajos de investigación que han centrado la mirada en el tema de la construcción simbólica del franquismo para abordar el estudio de las relaciones y conflictos entre las diferentes ideologías, élites y grupos sociales que componían el régimen. ${ }^{6}$ Estas

\footnotetext{
3 Ibídem, 314.

4 Una clasificación de los obispos integristas y aperturistas en las décadas de los sesenta y setenta puede verse en Martín de Santa Olalla 2005.

5 Esta división entre dos culturas políticas católicas dicotómicas en Moreno Seco 2011, 168-169.

6 Véase Saz Campos 2003; Box Varela 2008; Thomàs Andreu 2016; Baisotti 2017.
}

investigaciones se han ocupado - principalmente- de los años fundacionales del mismo, y de ellas han partido otras que han analizado cómo las diferentes ideologías coaligadas durante la dictadura franquista instrumentalizaron y resignificaron fiestas civiles y religiosas para mostrar, a través de esas prácticas rituales, el modelo social e ideológico de la España que cada una de ellas ambicionaba. ${ }^{7}$

Muchas de esas fiestas resignificadas tras la Guerra Civil eran complejos rituales integrados en lo que conceptualmente se conoce por religiosidad popular, es decir, un conjunto de creencias y prácticas de carácter religioso y colectivo, centradas en la iconodulía, a través de las cuales las comunidades locales interpretan y experimentan la trascendencia, su propia identidad cultural y su memoria colectiva. ${ }^{8}$ El campo de las fiestas religiosas populares supone un sincrético marco en el que se expresan actos rituales, icónicos, estéticos, emocionales, ecológicos, ideológicos, dionisíacos, orgiásticos y de diversión -esto es pluridimensionales y multisignificativos-, ligados a la identidad cultural de comunidades locales e imbricados con creencias y prácticas de carácter mágico-religiosas y de relación diádica con lo sobrenatural; ${ }^{9}$ un espacio socio-simbólico de hibridación en el que se dan la mano los imaginarios oficiales-institucionales de las élites - sean estos eclesiales o cívico-militares- y los imaginarios «populares». ${ }^{10}$ Los primeros suelen conferir una determinada bendición eclesiástica y un reconocimiento público a los segundos, mientras que los segundos proporcionan una profunda legitimidad social a los primeros y, así, ambos imaginarios se interfluyen. Las fiestas religiosas populares son, pues, hechos sociales totales donde se expresan, se ponen en movimiento y en relación la comunidad y sus instituciones - o una gran cantidad de ellas - y que implican varias dimensiones de la vida social y simbólica; fenómenos que, para su comprensión, deben ser abordados desde una perspectiva holística, integral, porque son un todo. ${ }^{11}$

Debido a esa interacción que se da en las celebraciones religiosas populares entre las comunidades celebrantes y las instituciones - representadas por élites locales religiosas y civiles-, estas prácticas rituales no están liberadas del control o de ciertas influencias eclesiásticas y políticas ni de constantes intentos de mixtificación, apropiación, utilización y reinvención. Las relaciones y tensiones que se expresan a través de ellas suponen un campo de estudio abierto por algunos antropólogos desde hace décadas, ${ }^{12}$ recuperados

7 Destacan Richards 2010; Hernández Burgos 2011, 263-319; Langa Nuño 2014; Navarro de la Fuente 2014; Rina Simón 2015, 2016 y 2017; Vincent 2017; Mancha Castro 2017, 2018 y 2020, entre otros.

8 El tratamiento conceptual del término religiosidad popular sigue siendo extremadamente polémico y se enfrenta a abiertos debates teóricos que aluden a la conveniencia o no de su uso. En este sentido, remitimos a Delgado Ruiz 1993 o Rodríguez Becerra 2011, que se muestra más partidario del uso de términos como religión popular o religión común.

9 Para atender a la temática de las funciones sociales e ideológicas de las fiestas religiosas populares, véase Rodríguez Becerra 1985, 172 y 175; Domene Verdú 2017.

10 Rina Simón 2015, 181 señala que, si «nos decantamos por el empleo del término "popular", debemos advertir la tendencia a relacionarlo con el concepto romántico de "pueblo", entendido como una comunidad espiritual - volkgeist - homogénea en su composición y "pura" en sus manifestaciones culturales».

11 Para el concepto de "hecho social total», véase Mauss 2009, 251-254.

12 Véase Moreno Navarro 1997, 1999 y 2006; Hurtado Sánchez 2000 . 
recientemente por esa nueva hornada de historiadores contemporáneos que destacamos con anterioridad para la aproximación a la construcción simbólica del franquismo.

Lo cierto es que el interés de los grupos políticos franquistas - principalmente del fascismo falangista y del nacionalcatolicismo tradicionalista - por instrumentalizar fiestas y rituales de religiosidad popular no suponía una novedad cuando comenzaron a hacerlo durante la Guerra Civil. Desde finales del XIX, tanto las jerarquías eclesiásticas como las élites económico-políticas de la Restauración habían ensayado todo un complejo de apropiación de la religiosidad popular. Las primeras estaban interesadas en hacer más ortodoxas esas prácticas religiosas, purificarlas de elementos costumbristas, integrarlas en sus normas, como una continuación y complemento de la labor evangelizadora y la liturgia de los templos. Las segundas pretendían exhibirse a través de ellas, mostrar su potestas, expresar y ritualizar el modelo social e ideológico reinante, y de ahí su interés por aburguesar las procesiones, militarizarlas, vincularlas a los ideales y símbolos de la monarquía española -en paralelismo simbólico con la monarquía suprema del reino de Dios- y, en última instancia, ligarlas a ideologías conservadoras y reaccionarias por medio de una invención de la tradición. ${ }^{13}$ Esta apropiación y vinculación simbólica de la religiosidad popular de finales del XIX y primeras décadas del XX con las élites e ideologías conservadoras resulta crucial para entender los estallidos de violencia iconoclasta que tuvieron lugar en la Segunda República y, sobre todo, al comienzo de la Guerra Civil por parte de los elementos más radicales del anticlericalismo y el izquierdismo socialista, comunista y anarquista. ${ }^{14} \mathrm{Y}$ esa «martirización de las cosas» sagradas ${ }^{15}$ serviría a las nuevas élites políticas y eclesiásticas nacionales para construir sus memorias de la guerra y todo un imaginario mediante el que interpretar y expresar la legitimidad del régimen naciente.

Los poderes políticos y militares franquistas se apropiaron de las celebraciones religiosas populares; las convirtieron en ritos petitorios por el triunfo del bando nacional $y$, tras éste, en ritos de celebración de la victoria; intensificaron su militarización, las utilizaron como plataformas de adhesión popular a los valores del régimen y, a través de ellas, ofrecieron una sincrética exhibición de liturgias paramilitaristas propias del fascismo - desfiles de piquetes de FET y de las JONS, saludos a la romana y gritos de «iArriba!»-, militaristas - desfiles de regimientos, piquetes de escolta o bandas - , ultranacionalistas - proliferación de himnos y banderas - y católicas. La jerarquía eclesiástica bendijo y amparó esas prácticas de politización de la religiosidad popular y, en los cortejos ceremoniales, se mostró en comunión con las autoridades civiles y militares, legitimando y compartiendo sus narrativas e imaginarios.

Durante los primeros años, el nuevo régimen se debatió entre dos modelos ideológicos para abordar la tarea de

13 Para el concepto de invención de la tradición véase Hobsbawm 2002.

14 Para una profundización en el antirritualismo católico y la función simbólica de la violencia iconoclasta y anticlerical, remitimos a Delgado Ruiz 2001 y 2005. Por su parte, la problemática de la cuestión religiosa durante la Segunda República ha sido ampliamente abordada por de la Cueva Merino 1998. Para el caso de Huelva, véase Espinosa Maestre 2005, 46-59 y 137-154; Mancha Castro 2018, 416-426 y 2020, 44-50.

15 Utilizando las palabras del obispo Antonio Montero Moreno. Cit. en Casanova Ruiz 2005, 193-194. su fundamentación: un modelo de Estado totalitario, como pretendían los componentes del fascismo falangista español, o un modelo de Estado corporativo, profundamente nacionalista y de confesión católica, como defendían los sectores y grupos nacionalcatólicos y tradicionalistas. Entre ambas corrientes ideológicas hegemónicas, unidas a partir del acto fundacional de la sublevación y la Guerra Civil, hubo confluencias y conflictos que permiten conceptualizar al franquismo de la guerra y la posguerra como la unificación de las derechas reaccionarias y contrarrevolucionarias en proceso de catolización y fascistización simultánea. ${ }^{16}$ Sin embargo, la bendición y legitimación que la Iglesia católica concedió a esa coalición reaccionaria $-y$ su integración en ella- resulta fundamental para entender la deriva del fascismo falangista y su posterior subordinación al ideario nacionalcatólico. La Iglesia y el catolicismo fueron «el alma del Nuevo Estado», ${ }^{17}$ un Estado que ligó su carácter nacional a su consustancialidad católica. ${ }^{18}$ La Iglesia y sus jerarquías nunca estuvieron subordinadas dentro del «bloque político y social» franquista ${ }^{19}$ y, para una parte de la historiografía española, ${ }^{20}$ su integración y poder en él fue determinante para entender el franquismo como un régimen fuertemente autoritario con procesos de fascistización, pero no como una religión política per se ni como una cultura política netamente fascista.

Durante estos años fundacionales, la Semana Santa onubense fue un fenómeno (re)inventado, profundamente transformado y engrandecido, mediante el que se canalizó un discurso ideológico que unificaba los valores del Nuevo Estado, sus distintas sensibilidades políticas y el integrismo doctrinal de la Iglesia católica del momento. Como hemos apuntado antes, se transformó en un espacio socio-simbólico de exhibición, intensamente controlado y dirigido por los poderes franquistas y eclesiásticos, en el que se hicieron representar en pública comunión las élites locales del Movimiento Nacional. En las presidencias de los desfiles procesionales, el clero y la jerarquía eclesiástica local se confundieron con militares y puestos políticos municipales y provinciales que se repartían falangistas, monárquicos tradicionalistas y alfonsino-juanistas y católicos rendidos a la causa franquista. Los cortejos penitenciales fueron inundados de prácticas militarizadas y fascistizadas que convivieron en simbiosis con las católicas y las propias de la cultura cofradiera local.

16 Saz Campos 2003, 159 señala que el fascismo falangista salió de la guerra catolizado mientras que las derechas tradicionalistas lo hicieron profundamente fascistizadas. Box Varela 2008, 198 también revela ese doble proceso de simbiosis ideológica que caracterizó el período fundacional de la dictadura: «la catolización del discurso fascista falangista y la fascistización del discurso nacionalcatólico y contrarrevolucionario».

17 Casanova Ruiz y Gil Andrés 2009, 257.

18 «La Semana Santa», Odiel, 10 de abril de 1938, 5: «Empieza la Semana Santa, con su bagaje de fiestas a celebrar por la Iglesia Católica y para cumplimiento del pueblo español, cuya catolicidad lleva en sus fibras como algo consubstancial y, por tanto, insuperable».

19 Compuesto, según Thomàs Andreu 2016, 17, por «el ejército, la Iglesia, el partido único creado en 1937, los carlistas de la Comunión Tradicionalista - no siempre integrados en el partido-, los alfonsinos - después juanistas - de Renovación Española, los ex cedistas, sectores patronales, empresariales, propietarios agrarios y aun decenas de miles de medianos y pequeños campesinos, sectores de las clases medias urbanas y rurales, etc., todos ellos católicos».

20 Remitimos a los citados Thomàs Andreu 2001; Saz Campos 2003; Box Varela 2008; Rina Simón 2016. 
Mediante las procesiones de Semana Santa, el clero y los poderes políticos franquistas construyeron, expresaron y difundieron sus propias narrativas y memorias sobre la guerra y la legitimidad sagrada de la dictadura. Resignificaron los símbolos religiosos populares, politizando hondamente la fiesta y ligándola a los reaccionarios valores nacionalcatólicos, contrarrevolucionarios y monárquicos, presentándola hasta mediados de los cuarenta con evidentes rasgos de fascistización. El objetivo -como con otras fiestas y rituales religiosos populares - fue servir a los propósitos del gran proyecto de recatolizar la ciudad, actuar como un rito de victoria, popularizar y bendecir el alzamiento y la represión, así como ritualizar la celebración del régimen. Las autoridades civiles y militares se presentaron como garantes de su celebración, articulando en torno a ella un discurso de mitificado nacionalismo español consustancialmente unido al ideario católico. Asimismo, rememoraron constantemente su trascendental intervención ante el calvario al que la fiesta fue sometida durante los años republicanos y los primeros días de la guerra en Huelva, destacando la palingenesia contenida en un imaginario que identificaba un triple paralelismo entre la pasión, muerte y resurrección de Cristo, la de España y la de la propia Semana Santa onubense:

Este año, por la paz que nos trajeron las armas victoriosas, la Semana Santa, como decimos, se ha celebrado con el máximo entusiasmo y renovado fervor. Quizá falten muchas imágenes veneradas que la horda destruyó en su loca vesania, pero la devoción erigió nuevos pasos y está aumentada por el recuerdo vivísimo de aquellos tres años que España sufrió su Pasión. ${ }^{21}$

A mediados de la década de los cuarenta, la Iglesia católica comenzó a distanciarse de esa mezcolanza de liturgias católicas y fascistas, pues entendía que la sagrada celebración de la Victoria ya había concluido. Hasta ese momento, la jerarquía eclesiástica había amparado todos esos mensajes de politización de lo sagrado deslizados en las procesiones. ${ }^{22}$ Pero, a partir de 1944, comenzó una tarea de purificación cortando ciertas expresiones políticas, las ligadas al fascismo, aunque manteniendo otras como la militarización y la exhibición pública de las élites políticas municipales. ${ }^{23}$

A raíz de la derrota del Eje y de la presión económica y política ejercida por Gran Bretaña y Estados Unidos, la dictadura emprendió un proceso de dulcificación de sus méto$\operatorname{dos}^{24} y$, al igual que la Iglesia, comenzó a suprimir parte de la simbología y praxis fascistas. Con estos ingredientes, el régimen se redefinió simbólicamente, emprendió un proceso de desfascistización y se fue configurando como un

21 Rebollo, A., "Huelva rindió a sus veneradas imágenes todo el fervor de su catolicidad», Odiel, 24 de marzo de 1940, 3.

22 Pedro Segura, arzobispo de Sevilla, había publicado, en marzo de 1938, una carta pastoral en la que afirmaba que las hermandades estaban «inseparablemente unidas a la vida no sólo religiosa, sino hasta cívica y militar». "Las cofradías y la vida cristiana», BOEAS, 15 de marzo de 1938. Cit. en Hurtado Sánchez 2000, 169.

${ }^{23}$ Así fueron desapareciendo en las procesiones los saludos a la romana, denunciados ya desde principios de los cuarenta por las jerarquías eclesiásticas, que ya no se sentían tan a gusto con esa hibridación y simbiosis ideológica y litúrgica, por lo que se afanaron en purificar de elementos fascistas la religiosidad popular. Para profundizar en la significación de la Semana Santa de Huelva con la dictadura durante la posguerra y el primer franquismo, remitimos a Mancha Castro 2017, 2018 y 2020.

24 En expresión de Casanova Ruiz y Gil Andrés 2009, 238. autoritario proyecto nacionalcatólico. Los grupos políticos cercanos a la Iglesia y sus jerarcas fueron ganando terreno en las esferas de poder, minimizando a los elementos falangistas y militares y jugando un papel protagonista en la dictadura durante la década de los cincuenta y principio de los sesenta. Con la imposición del ideario nacionalcatólico sobre el fascista falangista, la firma de un nuevo concordato con la Santa Sede en $1953,{ }^{25}$ la amistad con los Estados Unidos y la progresiva integración en las instituciones internacionales desde 1955, el régimen no peligraba y Franco comenzó a vanagloriarse de una España definida como la reserva espiritual de occidente.

Pero a finales de los años cincuenta y, más explícitamente, a partir de 1965 se operaron nuevas transformaciones ideológicas tanto en el seno del régimen como en el de la Iglesia. La liberalización económica y la industrialización y modernización emprendida por los tecnócratas coincidió con la celebración del concilio Vaticano II, fenómenos que, a la postre, serían fundamentales para comprender el desmoronamiento de la dictadura. ${ }^{26}$ La Iglesia de 1965 y - más aún - la de 1973 ya no era la del Concordato de 1953 ni -mucho menos - la de 1937. ${ }^{27}$ A lo largo de ese proceso de crisis y de profundas transformaciones ideológicas, se observaron tensiones que tuvieron visibilidad en las celebraciones de religiosidad popular como la Semana Santa. Conflictos entre un clero integrista preconciliar y un clero aperturista posconciliar, de éstos últimos con las cofradías y también con católicos adeptos y adláteres del régimen.

El objetivo de este artículo ha sido analizar las funciones sociopolíticas de la Semana Santa de Huelva y las instrumentalizaciones, expresiones de división eclesiástica y tensiones que en torno a ella se pusieron de manifiesto en el período de 1964 a 1975. Para abordar la consecución de este objetivo, las unidades de análisis han sido: 1) las cofradías y la Semana Santa, en atención a su modelo organizativo, ceremonial y al sistema de relaciones con las instituciones de poder; 2) el marco político, social e ideológico en el que se entiende el ritual en el período histórico determinado.

La metodología utilizada ha sido la propia de una etnografía de carácter histórico, basada en los presupuestos teórico-metodológicos de la antropología social y la historia cultural. Nuestra propuesta se ha basado en la fusión y utilización de los métodos y las técnicas de investigación propios de los antropólogos sociales y de los historiadores

25 El Concordato fue firmado el 25 de agosto de 1953 y fruto del mismo se constituyó la diócesis de Huelva. Apenas un mes antes, el 13 de julio de 1953, se comunicó al arzobispado de Sevilla la determinación de la Santa Sede de crear una nueva diócesis que comprendiera la región de la provincia civil de Huelva como sufragánea de la de Sevilla, con cuya archidiócesis seguiría manteniendo una estrecha relación. De esta forma, por la bula pontificia "Laetamur Vehementer», fechada en Castelgandolfo el 22 de octubre de 1953, fue nombrado el primer obispo de Huelva, monseñor Pedro Cantero Cuadrado. El 11 de febrero de 1954, el nuncio apostólico Ildebrando Antoniutti extendió un decreto que disponía la ejecución de la bula fundacional (Carrasco Terriza 2002).

26 En opinión de Raguer Suñer 1998, 34, «el Concilio actuó como fuente disolvente de la rigidez del franquismo».

27 Para acercarnos a las transformaciones de la Iglesia española, al cambio social y religioso y a las divisiones y tensiones eclesiales experimentadas en el segundo franquismo, véanse los trabajos de Raguer Suñer 1998; Moreno Seco 2002, 253-258 y 259-261 y 2008; Martín de Santa Olalla 2005; Montero García 2009 y 2011. 
contemporáneos, ${ }^{28}$ Ilegando a confundir al sujeto de conocimiento como un híbrido y no como un representante stricto sensu de una de las dos disciplinas. ${ }^{29}$ Se han utilizado diferentes fuentes para la producción de datos, destacando el trabajo de campo realizado en el Archivo Municipal de Huelva, en el Archivo de la Diputación Provincial de Huelva -más concretamente en su hemeroteca digital-, en el Archivo Histórico Provincial de Huelva y en varios archivos privados de algunas cofradías y diversos informantes. ${ }^{30} \mathrm{EI}$ diario Odiel, como prensa local del Movimiento, ha sido un venero fundamental que ha canalizado multitud de fuentes discursivas e informaciones relevantes para situar los hechos sociales y simbólicos analizados. El material fotográfico, emanado de archivos públicos y privados, ha resultado muy útil para la visualización de las relaciones de poder institucional expresadas en el complejo ritual, así como de los modelos estéticos y sus transformaciones. Y no menos relevante ha sido la literatura científica producida para el estudio del franquismo y la bibliografía divulgativa preexistente sobre la historia de la Semana Santa de Huelva.

\section{INSTRUMENTALIZACIONES POLÍTICAS Y TENSIONES INTRAECLESIALES EN TORNO A LA SEMANA SANTA ONUBENSE}

La década de los cincuenta representó aún un momento de cierta efervescencia en lo referente a la religiosidad popular, las cofradías y la Semana Santa onubense. Sin embargo, la fusión de elementos religiosos, políticos y festivos al servicio del régimen que hemos apuntado, hizo que paulatinamente se generara una profunda identificación de la Semana Santa como una fiesta de la dictadura y, a medida que fueron pasando los años, fue decayendo su popularidad y la participación en ella. La década de los sesenta y, sobre todo, el primer lustro de los setenta representaron un

28 «he tratado, sobre todo, de llevar la mirada y las preocupaciones teóricas del antropólogo al campo de la Historia; de convertirme en lo que los norteamericanos llaman un etnohistoriador» (Moreno Navarro 1997, 18).

29 «Entre los años sesenta y setenta, la historia cultural también adoptó lo que se ha llamado el giro antropológico. La historia comenzó a enriquecerse de los estudios antropológicos y, principalmente, del concepto de cultura. [...] Entre los antropólogos más estudiados por los historiadores estuvieron Marcel Mauss, Edward Evans-Pritchard, Mary Douglas y Clifford Geertz. Es éste el inicio de la NHC estadounidense y de la historia cultural francesa, concepto que rivaliza con otros de similar importancia, como la historia de las mentalidades o historia del imaginario social. Historiadores como Robert Darnton, Roger Chartier, Rhys Isaac, Emmanuel Le Roy Ladurie, Natalie Davis, Giovanni Levi, Carlo Guinzburg o Hanz Medick, representan el matrimonio antropología histórica o historia antropológica» (Hernández Sotelo 2010, 418-419). Para ahondar en el concepto, los paradigmas y las formas de proceder propias de la historia cultural, véase Burke 2006.

${ }^{30}$ Lamentamos la imposibilidad de acceder al Archivo Intermedio del Archivo Diocesano de Huelva. En él se encuentra todo el material que custodia la diócesis onubense sobre el tiempo histórico analizado, pero por su carácter de "archivo vivo» nos fue denegado su uso, únicamente reservado a la curia. Esta cuestión ha supuesto una limitación importante de cara a la consecución de ciertos objetivos específicos de la investigación. En este sentido, compartimos y denunciamos «los numerosos obstáculos con que se encuentran los investigadores que no provienen de medios eclesiásticos para acceder a los archivos de la Iglesia», coincidiendo con lo ya manifestado y denunciado por Moreno Seco 2002, 237. contexto de crisis, ${ }^{31}$ pues un conjunto de factores sociológicos, económicos, políticos e ideológicos ligados al éxodo rural, la secularización, la liberalización de las costumbres, la industrialización y la modernización y renovación que supuso el Vaticano II para la Iglesia católica, harían que se expresaran multitud de tensiones y conflictos en el plano simbólico.

Aun así, durante todo el segundo franquismo, las autoridades civiles y militares locales siguieron desarrollando en torno a la Semana Santa el proyecto de recatolización que se emprendió en la posguerra. Las instituciones públicas continuaron siendo una pieza clave para la organización estructural del ceremonial y mantuvieron una actitud de fomento e incondicional apoyo a la fiesta y las cofradías. Cada año, a través de la prensa local, se informaba de la realización de cuestaciones populares o de ayudas institucionales para atender los gastos ocasionados con motivo de la celebración. ${ }^{32}$ El ayuntamiento y el gobierno civil promovían la participación ciudadana en las procesiones publicando bandos y notas dirigidas en las que se alertaba de la suspensión del tráfico rodado en las calles del centro y de todo tipo de espectáculos que no se correspondieran con los de temática religiosa. ${ }^{33}$

A modo de intercambio simbólico por favores recibidos, algunas cofradías continuaron distinguiendo con cargos honoríficos a personas o instituciones civiles y militares, pero fue una práctica realizada con menor vehemencia y asiduidad que en los años del primer franquismo. ${ }^{34}$ Asimismo,

31 Hurtado Sánchez 2000, 232, también reconoce este proceso de crisis en la Semana Santa y la religiosidad popular sevillana.

32 Como ejemplo, en la cuaresma de 1969 , los hermanos mayores y el presidente de la Unión de Cofradías se reunieron con el entonces alcalde, Federico Molina, para comunicarle los graves inconvenientes económicos que tenían que enfrentar cada año para poder celebrar la Semana Santa y la necesidad de su ayuda. El regidor municipal les "prometió la solución de los principales problemas planteados»y, a partir de los años siguientes, la Unión de Cofradías se encargó del reparto directo de una subvención municipal fija para las hermandades. "Máxima ayuda a las cofradías onubenses», Odiel, 21 de marzo de 1969, 2.

33 A modo de ejemplo, dos notas de prensa de 1966 y 1974 alertando de tales restricciones: «Por respeto y recogimiento a estos solemnes días de Semana Santa, queda suspendido el tránsito rodado por el centro de la población, desde las tres de la tarde del Jueves Santo, hasta las nueve de la mañana del sábado» (Nota de la Alcaldía sobre la suspensión del tránsito rodado el Jueves y Viernes Santo), Odiel, 6 de abril de 1966, 10. "Con motivo de la celebración de Semana Santa, quedan suspendidos los espectáculos públicos, incluso sala de fiestas, desde las 12 horas del Jueves Santo día 11 de abril hasta la 1 hora del Sábado Santo día 13, sin más excepciones que conciertos sacros, representaciones teatrales o cinematográficas declaradas aptas para todos los públicos o menores de 18 años y otros análogos que cuenten con la autorización expresa del Ministerio de Información y Turismo». (Nota del Gobierno Civil sobre la suspensión de espectáculos públicos el Jueves, Viernes y Sábado Santo), Odiel, 10 de abril de 1974, 12.

34 Según Tello Camacho 1993, en mayo de 1965, la junta de gobierno de la hermandad de las Tres Caídas acordó otorgar el cargo de Hermano Mayor Honorario al director general de la Guardia Civil, que lo aceptó el 4 de junio de dicho año. Por su parte, la cofradía de los Estudiantes, aquejada por los problemas económicos y reunida en cabildo de oficiales, decidió «mandar una carta al Excmo. Sr. D. Manuel Lora Tamayo, ministro de Educación y Ciencia, solicitándole una ayuda para la Hermandad». El ministro, que desde la fundación de la corporación en 1949 era Hermano Mayor Honorario, contestó indicando que en próximas fechas mandaría la cantidad de diez mil pesetas (información extraída del acta de reunión de la junta de gobierno 
hubo hermandades que, adelantándose a los sucesos políticos y, con toda probabilidad, movidas por los influjos de carácter monárquico de algunos de sus directivos, acordaron nombrar Hermano Mayor Honorario a Juan Carlos de Borbón. ${ }^{35}$

Pero, como ya hemos señalado, la relación entre las cofradías y las élites y poderes políticos y militares no sólo fue de intercambios simbólicos. La fuerte dependencia estructural y económica que mantenía la Semana Santa con las diferentes instituciones derivaba en una especie de red clientelar de verdadero control, que aseguraba el mantenimiento de una connivencia ideológica entre estas corporaciones, su ceremonial público y las esferas de poder del régimen. Un control que también sería ejercido por la jerarquía eclesiástica local integrista y preconciliar, sobre todo durante el pontificado de Pedro Cantero Cuadrado y, en menor medida por su reducida duración, en el de José María García Lahiguera.

A la altura de 1962, año en que se convocó el concilio Vaticano II, la estancia de Cantero Cuadrado en Huelva estaba finalizando. Para la Semana Santa de 1963 y junto al gobernador civil Hernán Pérez Cubillas, autorizó la realización de una cuestación pública a petición de los hermanos mayores de las cofradías. El prelado participó en ella con la aportación de dos mil pesetas. En la Semana Santa de 1964, Cantero se hizo cargo del pago de los salarios de las cuadrillas de costaleros que portaron los pasos de Virgen. El desembolso fue de cincuenta y cinco mil seiscientas cuarenta pesetas. $^{36}$

La relación de Cantero Cuadrado con las cofradías fue de absoluto control y sustento. Como obispo, no erigió canónicamente a ninguna cofradía de penitencia, al haberse fundado masivamente éstas entre 1940 y 1951, antes de la creación de la diócesis onubense. ${ }^{37}$ Sin embargo, participó en multitud de cultos, actos institucionales, nombramientos honoríficos y desfiles procesionales. Promovió una reforma estructural y normativa de la Comisión de Cofradías para convertirla en el Consejo General de Cofradías y permitió

de la hermandad de los Estudiantes, 13 de febrero de 1968). Al igual que hicieron otras corporaciones penitenciales en los años fundacionales de la dictadura, la única hermandad fundada en el segundo franquismo, la del Calvario, invitó a élites locales a apadrinar la bendición de sus imágenes titulares. La del Cristo del Calvario tuvo como padrinos a Vicente Rodríguez Casado y a Pilar Carvajal. Odiel, 15 de abril de 1973, 16. Rodríguez Casado era un destacado miembro del Opus Dei, presidente del Patronato del Instituto Politécnico y rector de la Universidad Hispanoamericana de la Rábida, mientras que Carvajal era la esposa del entonces alcalde de Huelva, Diego Sayago Ramírez. La Virgen del Rocío y Esperanza, por su parte, fue apadrinada por el presidente de la Cámara de Comercio, Industria y Navegación, Miguel Martín Navarro y su esposa, contando el acto con la presencia del alcalde de la ciudad. Odiel, 5 de enero de 1974, 12.

35 Así lo hizo la cofradía del Santo Entierro en 1965. «Reglas y estatutos de la hermandad del Santo Entierro», p. 3: «En la actualidad es Hermano Mayor Honorario S. M. el Rey D. Juan Carlos I, que acepta su nombramiento el 26 de mayo de 1965». La hermandad de Pasión, por su parte, le otorgaría el citado título honorífico en 1972, tres años después de que Franco le designara como su sucesor en la jefatura de Estado a título de rey. El entonces príncipe aceptaría la propuesta de la cofradía en marzo de dicho año. Odiel, 18 de marzo de 1972, 11.

36 Remitimos a Sugrañes Gómez 2000, 34, que extrajo la información del acta del pleno del Consejo de Cofradías en sesión de 18 de marzo de 1964, folio 14, libro primero.

37 Véase Mancha Castro 2017, 2018 y 2020. todo tipo de actuaciones en pro de las hermandades. Su pontificado coincidió con la existencia de una curia envejecida, reaccionaria y tradicionalista que, al igual que él, veía en Franco al enviado providencial y salvífico de España y en las cofradías un poderoso instrumento social y ritual de utilidad política al servicio de la Iglesia, de su memoria y sus imaginarios, fusionados éstos con los del propio régimen. ${ }^{38}$ En años anteriores, esa curia había fomentado y apoyado la masiva fundación de corporaciones penitenciales para servir al proyecto de recatolización de la ciudad. Un apoyo que, la nueva curia que estaba naciendo del Vaticano II y que - por razones biológicas - pronto la sustituiría, cambiaría en años sucesivos. ${ }^{39}$

El fin de la tarea de Cantero Cuadrado en la diócesis de Huelva llegó poco después de la Semana Santa de 1964, al ser nombrado arzobispo de Zaragoza. Su sustituto fue José María García Lahiguera, obispo que debió desarrollar y aplicar las normas conciliares en la sede onubense. Sin embargo, su pontificado duró sólo cinco años y, en realidad, el prelado estaba poco interesado en esa tarea de profunda renovación eclesial; la veía como un error, como una desviación, con la misma percepción que lo harían la Junta de Metropolitanos entre 1965 y 1966 y la Conferencia Episcopal española entre 1966 y $1971 . .^{40}$ Era natural, pues

38 Afirman Casanova Ruiz y Gil Andrés 2009, 249 que, como dirigente de la Iglesia de Franco, Cantero «llevó su compromiso más lejos, hasta mancharse en la democracia orgánica montada por el Caudillo salvador». Estudió Humanidades, Filosofía, Teología y Derecho, pero puso toda su ciencia al servicio del Movimiento. Fue un prelado consagrado a las formas tradicionales católicas y su compromiso con la dictadura quedó reflejado en su currículum como capellán del arma de Caballería durante la guerra, asesor nacional de Cuestiones Morales y Religiosas del Auxilio Social desde 1939, procurador en Cortes, consejero del Reino y miembro del Consejo de Regencia. Cargos políticos que Cantero aceptó - según él- «por un deber de fidelidad a Franco y a las Leyes Fundamentales» (Martín de Santa Olalla 2005, 259).

39 Los representantes del viejo clero integrista de Huelva iban desapareciendo paulatinamente. El 10 de mayo de 1957 había fallecido José Manuel Romero Bernal y, el 21 de junio de 1970, cinco años después de la conclusión del concilio, lo haría Pablo Rodríguez González. Ambos, junto a Julio Guzmán López, Luis Pardo Gil y José Muñoz Blanco, eran los representantes más destacados de la antigua generación de sacerdotes que había vivido al abrigo de la ideología del nacionalcatolicismo. Tras el fallecimiento de Pablo Rodríguez el 21 de junio de 1970, el cronista Diego Díaz Hierro realizó una reseña sobre su persona en «Un sacerdote ejemplar», Odiel, 26 de junio de 1970, 11. En el artículo podíamos leer las cuatro facetas principales que rigieron su apostolado, siendo una de ellas «su gran amor a la Patria. Su patriotismo, guardado en la urna de la mesura más adorable, valía verdaderos quilates. Era el número uno de esa pléyade de sacerdotes que han reconocido en Franco no sólo al salvador de España, sino al ángel custodio y protector de su hermosa religiosidad. Humildemente, sin estridencias ni pompa alguna, no perdía ocasión, aún después de las incomodidades y dolencias de su enfermedad, aún después de pasadas las emociones y fervores de los primeros momentos, de demostrar su gratitud a los poderes públicos, sobre todo en las recepciones oficiales de algunas efemérides patrióticas, con lo que se quedaba gozosamente satisfecho del deber cumplido».

40 La Junta de Metropolitanos era el órgano directivo de la Iglesia española antes de que el concilio instituyera las conferencias episcopales. Los obispos españoles que fueron mayoría en ambas instituciones eclesiásticas hasta 1971 se «habían formado con los residuos de la decadente cultura eclesiástica barroca postridentina, pasada por el tamiz de la "cruzada" franquista. Era una teología metafísica, concebida para discusiones abstractas pero incapaz de afrontar los problemas reales de la Iglesia y de los hombres contemporáneos» (Raguer Suñer 1998, 36). 
García Lahiguera también fue un obispo muy vinculado al régimen de Franco y jamás comprendió esa transformación eclesial para conectarse con la modernidad, ni los propósitos del papa Pablo VI, ni la tensa relación establecida entre la Santa Sede y una dictadura en la que muchas jerarquías de la Iglesia española tenían tanto poder. ${ }^{41}$ No en vano, había llegado a la diócesis de Huelva con la pretensión de apaciguar los posibles conflictos intraeclesiales fruto de las interpretaciones conciliares y con el objetivo de controlar el cumplimiento de la obra iniciada por Cantero, complementarla y llevarla a su culmen. ${ }^{42}$

Su relación con la Semana Santa y las cofradías no fue tan intensa como la de Cantero Cuadrado, pero sí lo suficiente como para que las hermandades de Pasión y de la Buena Muerte le concedieran el título de Hermano Mayor Honorario..$^{43}$ Fue su intención continuar la labor de purificación, dirección y control puesta en marcha por su predecesor, así como establecer un vía crucis cuaresmal como acto de penitencia pública, obligatoria y oficial en el que debían participar todas las hermandades. Este vía crucis fue una realidad entre 1966 y 1969, coincidiendo el cese de dicho acto piadoso con el fin de su pontificado.

Tras la marcha de García Lahiguera al arzobispado de Valencia, en noviembre de 1969 fue nombrado obispo Rafael González Moralejo. ${ }^{44}$ Pero a diferencia de Cantero Cuadrado y de García Lahiguera, González Moralejo fue un prelado aperturista que participó en el frente de las

41 Martín de Santa Olalla 2005, 59 lo define como «uno de los obispos más cercanos al Régimen». Por $A B C, 4$ de julio de 1969, sabemos que durante la Guerra Civil permaneció en Madrid, zona republicana, y, a su finalización, fue recompensado con la medalla del soldado en vanguardia. En palabras de Casanova Ruiz y Gil Andrés 2009, 297 "José María García Lahiguera [...] resumió en la homilía del funeral celebrado por Franco en su sede episcopal las tres principales virtudes del Caudillo al que tanto admiraba: 'Ser hombre de fe; entregado a obras de caridad, a favor de todos, pues a todos amaba; hombre de humildad'».

42 «Quienes le conocían en el Gobierno de la nación, el mismo Jefe del Estado, deseaban que fuera destinado a una diócesis, como persona no conflictiva en un momento en que se auguraban tensiones con la Iglesia debido a los nuevos aires conciliares [...], poniendo en él la esperanza de que sería el hombre que complementaría y llevaría a su culmen la obra iniciada por Cantero. El mismo don Pedro Cantero comentó a la llegada de don José María [...]: "Yo he montado la estructura material y jurídica de la nueva diócesis; don José María sabrá darle la auténtica fisonomía espiritual de Esposa de Cristo" " (Carrasco Terriza 2002, 548).

43 Conocemos que el prelado aceptó el nombramiento en la cofradía de Pasión el 11 de octubre de 1964. Véase http://www.hermandaddepasion.com/wp/historia/. Por su parte, sabemos que fue nombrado Hermano Mayor Honorario de la cofradía de la Buena Muerte por una entrevista al secretario de la hermandad, José Tomás de las Cuevas, publicada en Odiel, 10 de abril de 1973, 11.

44 González Moralejo era licenciado en Química y doctor en Económicas. Participó activamente en el concilio Vaticano II, siendo uno de los principales redactores de la constitución "Gaudium et Spes» junto a Karol Wojtyla, en ese momento arzobispo de Cracovia, con quien mantuvo desde entonces una estrecha relación. En palabras del sacerdote onubense Carrasco Terriza 2002, 558-559: «La situación de la Iglesia a la llegada de don Rafael mostraba ya unos preocupantes problemas. [...] El rápido descenso de las vocaciones fue una primera señal de alarma. El desmoronamiento de las formas unitarias de apostolado en la A. C. dio paso a múltiples asociaciones y movimientos, independientes entre sí. [...] El clero acusó los efectos de la crisis social e ideológica y la crisis de identidad sacerdotal. Se produjo una dolorosa cadena de secularizaciones». tensiones generadas entre la Iglesia y el Estado. Desde 1958 era auxiliar del cardenal Marcelino Olaechea en el arzobispado de Valencia y, a la altura de 1966, González Moralejo ya «era el líder de los obispos españoles plenamente conciliares ». ${ }^{45}$ Cuando Vicente Enrique y Tarancón comenzó a presidir la Conferencia Episcopal en 1971, la labor de González Moralejo en esas tensiones entre la Iglesia y el Estado se visibilizaría aún más. Firmó y distribuyó el polémico documento "Justitia et pax», que se constituyó en una comisión que él mismo presidió, integrada en la Comisión Episcopal de Apostolado Social. Asimismo, perteneció a la Comisión Permanente de la Conferencia Episcopal de Tarancón y a la conocida como "Comisión de los 7», encargada de redactar el documento de la ponencia «La Iglesia y la Comunidad Política», publicado el 23 de enero de $1973 .{ }^{46}$ En Huelva, González Moralejo puso en marcha la tarea de profunda renovación eclesial diocesana. Durante sus primeros años de ministerio aplicó las disposiciones del Vaticano Il y forjó la nueva estructura de la Iglesia local posconciliar, dirigiendo también las tensiones y los esfuerzos de transformación de la institución durante el tardofranquismo.

\section{FOTOGRAFÍA 1 \\ Franco y González Moralejo conversan durante el acto de presentación del nuevo obispo preconizado de Huelva ante el Jefe del Estado, que tuvo lugar en el palacio de El Pardo a primera hora de la tarde del 9 de diciembre de 1969. ${ }^{47}$}

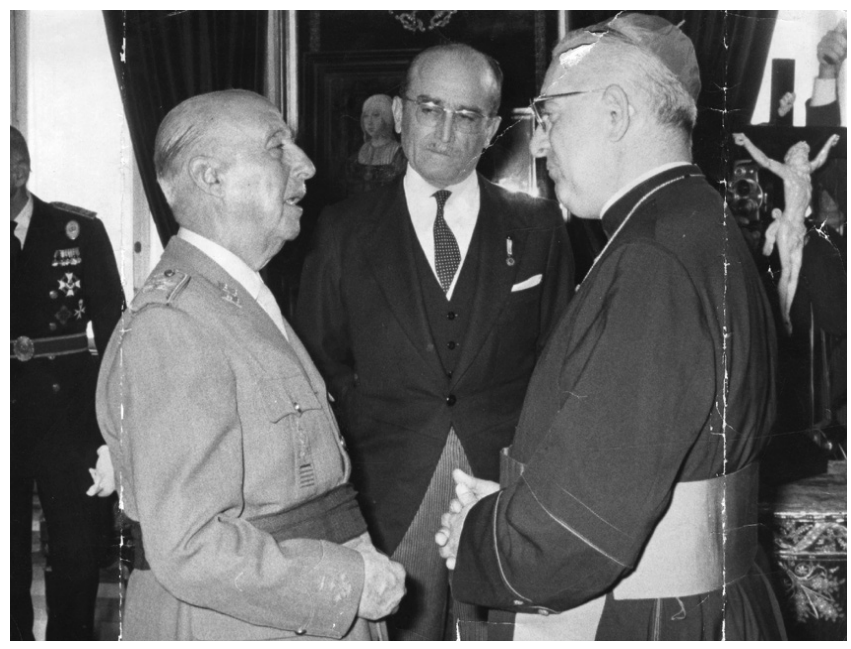

Fuente: Fotografía de archivo del diario Odiel. Archivo Histórico Provincial de Huelva (Fondo 213).

Lo cierto es que en lo referente a la religiosidad popular, tanto García Lahiguera como, en sus primeros años, González Moralejo vivieron un tiempo de incipiente depresión en torno al mundo de las cofradías y la Semana Santa, resultado de múltiples y complejos factores sociológicos, económicos e ideológicos, además de como consecuencia de las nuevas interpretaciones posconciliares de un clero local en renovación. En 1966, García Lahiguera y Cantero

45 Raguer Suñer 1998, 44-45.

46 Una caracterización más extensa y profunda sobre González Moralejo en Martín de Santa Olalla 2005.

47 La reseña del acto de presentación puede leerse en Odiel, de 10 de diciembre de 1969, 2. 
Cuadrado habían conferido el presbiteriado a la primera hornada de sacerdotes formados en el seminario de Huelva. ${ }^{48}$ Unos sacerdotes que, en su mayoría, no estaban interesados en esa iniciativa de control sobre las hermandades ni de atención a la religiosidad popular como mecanismo de legitimación social del nacionalcatolicismo. ${ }^{49}$ Una curia que se fue distanciando de la religiosidad popular, que la criticaría y que, debido a la identificación de la Semana Santa y otros rituales religiosos populares como fiestas más del régimen que de la propia Iglesia, se iría identificando más y mejor con las nuevas comunidades cristianas de base y otros movimientos apostólicos, más centrados en vivir una fe razonada desde la experiencia comunitaria y sirviendo a la construcción social del mundo que una religiosidad sentida desde la iconodulía y la ritualización de una exhibición vanidosa que tanta vinculación guardaba con la dictadura. ${ }^{50}$

La desvinculación o "desenganche ${ }^{51}$ de la Iglesia de la dictadura franquista se produjo a lo largo de un proceso desarrollado entre el segundo lustro de los sesenta y el primero de los setenta, marcado por las nuevas directrices conciliares y la estrategia ideada por el papa Pablo VI y el nuncio Dadaglio, que fue ejecutada por Tarancón y los obispos aperturistas - la mayoría de ellos auxiliares - de la Conferencia Episcopal española. ${ }^{52}$ Los obispos auxiliares resultaron ser el brazo ejecutor adecuado para materializar

\section{Carrasco Terriza 2002.}

49 A medida que iba desapareciendo el viejo clero, el patriotismo se fue separando de la esfera de lo religioso, evidenciando el particular fin del nacionalcatolicismo. La nueva curia estaba más centrada en el mensaje del Evangelio y en la construcción social del mundo y, en los últimos diez años del franquismo, algunos curas ampararon reuniones vecinales, sindicales y políticas clandestinas en el interior de las parroquias. En este sentido, véase Feria Vázquez 2009, 83-91.

50 Parece evidente que esa etapa de crisis de las cofradías y de éstas con el clero podría estar muy en relación con la crisis que se vivió a finales de los años sesenta y principio de los setenta en el seno de la Acción Católica Española. Tal y como se expresaba en las conclusiones de las VIII Jornadas Nacionales de la ACE de 1967: «La acción pastoral de la Iglesia requiere la existencia de grupos fuertemente encarnados y comprometidos en su ambiente, capaces de cristianizarlo y de llamar a la conversión mediante su testimonio. Pero también se necesitan comunidades eclesiales acogedoras, abiertas, renovadas, capaces de integrar a cuantos lleguen procedentes de diversos ambientes» (cita extraída de la ponencia de Pedro Escartín Celaya, de 2009, titulada «De aquella a esta Acción Católica General»). Unos postulados que no se correspondían con las funciones que jugaban las hermandades en el seno de la Iglesia, con un nivel de compromiso bastante laxo y más orientadas a organizar rituales públicos basados en una religiosidad trascendente y emocional.

51 Moreno Seco 2008, 145; Montero García 2009; Ruiz Andrés 2017, 216. Moreno Seco 2008, 145 y Montero García 2011, 52 también utilizan el concepto «despegue».

52 «La Conferencia Episcopal Española, creada en 1966, fue el escenario del conflicto entre obispos conciliares y conservadores. En la CEE existía una división entre obispos afines al Régimen, como Morcillo, arzobispo de Madrid, Guerra Campos o Castán Lacoma, y otros conciliares, entre quienes se contaban Tarancón, Bueno Monreal, Quiroga o Tabera. El nombramiento de obispos auxiliares, que no necesitaban pasar por el trámite de la presentación, permitió una renovación del episcopado español, impulsada por el nuncio Dadaglio y Pablo VI. Los nuevos nombramientos hicieron que los prelados conciliares pasaran a mayoría y Tarancón fue elegido presidente de la CEE en 1971. Desde este cargo y como arzobispo primero de Toledo y después de Madrid se convirtió en un personaje clave en la transición de la propia Iglesia española, hacia un progresivo alejamiento del franquismo» (Moreno Seco 2008, 160). la estrategia de Pablo VI y Dadaglio ya que, por razón del Concordato de 1953, eran los únicos nombrados directamente por el Vaticano sin intromisión de las autoridades del régimen. El proceso se produjo a dos niveles: el ideológico y el político. En la esfera de lo ideológico, los prelados aperturistas se afanaron en combatir y destruir la tesis de la consustancialidad entre españolismo y catolicismo y en desligar la pertenencia del ideario católico a los proyectos políticos reaccionarios franquistas. Este hecho suponía el viraje de una parte importante de la Iglesia hacia la aceptación de la pluralidad ideológica, la aprehensión de un nuevo relato de deslegitimación del nacionalcatolicismo y la proclamación del brote múltiple de diferentes ideologías y proyectos políticos que podían surgir empapados de la fe y las fuentes del evangelio. En la esfera política, esto suponía que la Iglesia apostataba de la coalición y del proyecto político de la dictadura, y significó la generación de un clima de tensión y confrontación continua de la Conferencia Episcopal y la Santa Sede con el gobierno. ${ }^{53}$

Fruto también de esa tensión y división, en 1969 se constituiría la Hermandad Sacerdotal Española, una asociación de sacerdotes y religiosos representantes de las posturas reaccionarias, conservadoras y tradicionalistas, y vinculados a las tesis del obispo Guerra Campos. La Hermandad Sacerdotal se opuso a la renovación posconciliar y a los cambios sociales y políticos que se sucedieron en la España del tardofranquismo. Su misión fue combatir las posiciones del clero progresista, abogar por el mantenimiento de las formas tradicionales preconciliares en la misa y la liturgia, oponerse a la desaparición del espíritu de la Iglesia de la Cruzada - sintetizado en la Carta Colectiva de 1937- y defender la confesionalidad católica del Estado.

Desde la finalización del concilio, la dualidad entre las posiciones eclesiásticas preconciliares y posconciliares sería objeto de análisis en las esferas culturales de Huelva. En diciembre de 1965, el Ateneo organizó una mesa redonda a celebrar en el Círculo Mercantil y Agrícola para debatir la obra "Los nuevos curas» de Michel de Saint Pierres. ${ }^{54}$ En la mesa intervinieron hombres de la cultura onubense del momento y diversos sacerdotes cercanos a los postulados renovadores. ${ }^{55}$ La dicotomía entre curas viejos frente a curas nuevos era motivo de debates y artículos de opinión como el publicado por Guillermo Alonso del Real. Este señor, que había sido el pregonero de la Semana Santa de ese año de 1965 y que por entonces era catedrático de Instituto de Enseñanza Media y delegado provincial del ministerio de Información y Turismo, advertía del flaco favor que se le hacía a la Iglesia

53 «Ese desajuste entre la proclamada identidad católica del Régimen y la nueva doctrina de la Iglesia es lo que explica la radicalidad de la tensión Iglesia-Estado en los últimos gobiernos de Franco» (Montero García 2011, 53).

54 Como señala Montero García 2011, 74, no debemos ignorar que las «expresiones de división y tensión en la Iglesia española, aunque con sus características particulares por la peculiar situación española, se inscriben en un contexto postconciliar que afectó a todas la Iglesias, provocando por ejemplo reacciones anticonciliares de ámbito nacional e internacional. La división tenía un trasfondo doctrinal que afectaba a la interpretación y aplicación de los documentos conciliares. En el caso español sin duda tenía una dimensión política mayor que en países democráticos como Francia, Alemania, Italia, donde estaba ya bien asentada una tradición demócrata-cristiana».

55 Odiel, 5 de diciembre de 1965, 3. 
incrementando el morbo ante supuestos enfrentamientos entre ambas posturas eclesiásticas. Sin embargo, él mismo reconocía la existencia de una dualidad. ${ }^{56}$

Una dualidad que quedaría expresada a través de la vestimenta utilizada por los sacerdotes a partir de finales de los sesenta. La introducción del clergyman haría que se percibieran visualmente las posturas de los componentes del clero. El traje talar se asoció a la imagen de los curas más reacios al concilio, mientras que el clergyman marcaría a aquellos más cercanos a los postulados del Vaticano II. El joven canónigo doctoral onubense Juan Mairena fue el primer eclesiástico español en utilizarlo a su regreso de Italia. A la altura de 1966, el padre Mairena reconocía que el empleo del clergyman aún no estaba autorizado en la diócesis de Huelva, pero que era un hábito que venía realizando porque sí estaba permitido en Roma, donde había estado ampliando estudios. ${ }^{57}$

En la esfera de la religiosidad popular, el concilio y el aperturismo habían supuesto la aparición de una praxis religiosa radicalmente opuesta a la tradicional. Las interpretaciones que se hicieron del Vaticano II derivaron en la práctica de una nueva religiosidad más razonada que emocional, despojada de múltiples elementos ornamentales definidos como accesorios-, y de una nueva pastoral más centrada en la construcción social del mundo que en el culto público a la divinidad. ${ }^{58}$ Se trataba de la conformación de un cristianismo nuevo, sin tanta ritualidad -o con una ritualidad menos política-, centrado en los elementos esenciales de la liturgia y despojado de todo aquello que condujera a una interpretación mistérica o mágica del culto. La interpretación hegemónica que se hizo de las nuevas bases conciliares restaba valor a las manifestaciones populares como las procesiones y los actos de piedad, desnudaba las iglesias y enfatizaba una nueva actitud iconoclasta, donde el altar, el sagrario y apenas un crucifijo componían el nuevo marco cultual.

Esta situación traería una fuerte carga de críticas hacia las cofradías y la Semana Santa, lanzadas - principalmente- por los curas y seglares renovadores y aperturistas, impregnados por un espíritu de conversión que debía trascender las prácticas piadosas y de religiosidad popular de carácter tradicional que tan vinculadas estaban a la política y la identidad nacional posguerracivilística y tan desvinculadas estaban de esa renovada lógica y religiosidad pregonada ahora por esa nueva Iglesia surgida del concilio: «la Iglesia está viviendo su primavera conciliar. [...] Esta primavera de la Iglesia nos exige un cambio de mentalidad. [...] Elegir una piedad litúrgica fundamental, entre una serie de 'devocioncitas' accidentales ${ }^{59}$

56 Alonso del Real, G., "Algo sobre curas nuevos y viejos», Odiel, 5 de diciembre de 1965, 3.

57 La revista Dígame, 19 de julio de 1966, ofreció un artículo sobre esta prenda y una entrevista al joven sacerdote onubense, cuya estética se contraponía a la del también onubense Manuel Gil González, un cura tradicional que prefería el uso del traje talar. El artículo fue hallado en la carpeta 207 del Fondo Díaz Hierro del Archivo Municipal de Huelva.

58 En palabras de Moreno Seco 2008, 155, una nueva pastoral que ponía el énfasis en la «primacía del compromiso sobre la anterior espiritualidad».

59 T. M., «Primavera», Odiel, 20 de marzo de 1966, 12.
La nueva Iglesia que nacía del Vaticano II comenzaba a repudiar esas prácticas rituales, que empezó a catalogar como accesorias y que guardaban una imagen de connivencia con un régimen político del que pretendía desligarse. Unos sacerdotes que, en su mayoría, no estaban interesados en esa secular iniciativa de control sobre las hermandades en la que sí convergían las autoridades políticas franquistas y los eclesiásticos integristas preconciliares. Más bien al contrario, decidieron ignorarlas, como si fueran una herencia casi herética, un tipo de piedad mágico-religiosa sin valor para la nueva pastoral, recibida de un pasado incompatible con el nuevo mensaje de transformación eclesial.

También en la esfera pública y de los medios de comunicación comenzaba a generarse una polémica y debate permanente en torno al concilio, su aplicación y las interpretaciones que -basándose en el mismo- muchos hicieron de la religiosidad popular. Se empezó a tachar a las devociones y las prácticas religiosas populares como errores y desviaciones o, en el mejor de los casos, como algo accesorio - totalmente secundario y hasta prescindible- de la práctica litúrgica.

Algunas manifestaciones de religiosidad [...] quedan expuestas al airecillo de espíritu crítico que sopla cada día con mayor fuerza y sometidas por él a una labor de aventado discriminatorio de trigo y paja, separando la adhesión verdaderamente personal y activa a la fe de concepciones mágicas del mundo y de las pervivencias supersticiosas. [...] La auténtica veneración y el respeto a las imágenes, por ejemplo, es cosa bien distinta del afán inmoderado de besarlas y tocarlas; más aún si el afán hace explosión en fecha fija, con el aliciente de conseguir favores, las más de las veces materiales, solicitados en interesada terna. [...] Si deseamos que nuestras manifestaciones religiosas se liberen de degradaciones mágicas y de reminiscencias supersticiosas que desacreditan la religión y empujan hacia el ateísmo hemos de emprender seriamente la tarea de educar por la Liturgia. ${ }^{60}$

El pregón de la Semana Santa de 1968 representó una muestra de la tesitura en que se encontraba la relación entre el clero renovador y las cofradías. El encargado de pronunciarlo fue monseñor José María Cirarda Lachiondo, por entonces obispo auxiliar de Sevilla. ${ }^{61}$ En lugar de realizar un pregón cofradiero al uso, el prelado se dedicó a exponer su posición acerca del papel que debían jugar las cofradías en el nuevo tiempo que vivía la Iglesia. Su exposición se basó en analizar si las hermandades tenían sitio dentro de la renovada institución, concluyendo que para él sí lo tenían pero que era un sitio condicionado. Condicionado a la adecuación 12.

60 I. F., «Diálogo al más alto nivel», Odiel, 20 de marzo de 1966,

61 Cirarda era un obispo de la corriente aperturista, por entonces auxiliar del cardenal Bueno Monreal en el arzobispado de Sevilla. Licenciado en Filosofía y Teología, de ideología nacionalista vasca, había sido objeto de veto por parte del régimen hasta que, en 1960, fue consagrado obispo auxiliar. Participó en las tres sesiones del concilio Vaticano II, siendo el eclesiástico que sirvió de enlace con la prensa española. Pocos meses después de pregonar la Semana Santa onubense en 1968 fue preconizado obispo de Santander y, en noviembre del mismo año, nombrado simultáneamente administrador apostólico de Bilbao hasta 1971, año en que fue trasladado a la diócesis de Córdoba. Ya en 1978 sería preconizado arzobispo de Pamplona, donde permanecería hasta su renuncia. 
de las mismas a las nuevas bases apostólicas, caritativas y de cumplimiento sacramental emanadas del concilio, es decir, a la unión entre una práctica litúrgica basada en lo fundamental -y desprovista de barroquismo accesorio- y la lucha por la transformación social del mundo. ${ }^{62}$

Sin embargo, más allá de las palabras de obispos como Cirarda estaban los hechos de los párrocos que, en general, se encontraban en clara disidencia con los cofrades, las hermandades y todo su sincrético y ampuloso ritual. Durante la década de los sesenta fueron dejando de participar en el sitio que tradicionalmente ocupaban en las procesiones, esto es, encarnando la figura del preste tras el último paso de la cofradía. ${ }^{63}$ A la altura de 1968, y a excepción de la procesión del Santo Entierro, ya no había curas que participaran como prestes en la Semana Santa. ${ }^{64}$

Una disidencia que se podía intuir también observando la arquitectura de la mayoría de las iglesias que fueron construidas $-\mathrm{y}$ reconstruidas - en la ciudad entre mediados de los sesenta y principio de los setenta. Se desnudaban los altares y se eliminaba todo lo que se identificara con suntuosidad y barroquismo. ${ }^{65}$ Algunos templos de nueva factura fueron situados en locales de planta baja sobre los que se alzaron edificios de viviendas, mientras otros incluían grandes escalinatas y pequeñas puertas para evitar que allí pudieran instalarse cofradías.

Con anterioridad a 1966 existían en Huelva nueve templos; entre 1966 y 1971 se edificaron otros nueve. ${ }^{66}$ Las parroquias fundadas y construidas durante estos años fueron Cristo Sacerdote (1966), San José Obrero (1968), Santa María

62 La reseña que la prensa realizó sobre el pregón de Cirarda Lachiondo la encontramos en un recorte sito en la carpeta 1056 del Fondo Díaz Hierro del Archivo Municipal de Huelva.

63 La figura del preste hace referencia a un eclesiástico - normalmente el párroco o el director espiritual de la cofradía- que participa al final de la procesión revestido con capa pluvial y suntuosos ropajes bordados, siendo acompañado por dos acólitos o sacristanes que lo escoltan portando cirios. Se trataba de una figura propia de la liturgia barroca preconciliar y que se mantuvo en los cortejos ceremoniales de la Semana Santa onubense hasta finales de la década de los sesenta, aunque - bien es cierto- ya venía diluyéndose pausadamente desde los últimos años de los cincuenta.

64 Según las crónicas del diario Odiel, las hermandades de la Vera Cruz y Oración, la Cena, los Mutilados, San Francisco, los Judíos, e Descendimiento, el Santo Entierro, el Silencio, la Borriquita y las Tres Caídas continuaron siendo acompañadas del preste, al menos hasta 1968, año en el que encontramos la última referencia sobre esta figura.

65 El paradigma neobarroco se había convertido en la fuente de sentido estética y expresiva de la Semana Santa franquista y poseía una determinada significación política. Dentro de las tendencias historicistas, el neobarroco se erigió como el movimiento artístico dominante en todas las representaciones plásticas españolas, sobre todo en las de temática religiosa, y los modelos estéticos de las cofradías que se fundaron o reorganizaron tras el conflicto bélico no fueron una excepción. Como bien han estudiado di Febo 1988, Richards 2010, Barreiro López 2014 o Vincent 2017, ese paradigma neobarroco que fue instituido en toda la España nacionalcatólica evocaba las épocas doradas y gloriosas del imperio español y los tiempos de la Contrarreforma, cuando el catolicismo contestaba a los presupuestos ideológicos del protestantismo. Fue, pues, un movimiento que despertó al socaire de una fuerte transformación ideológica y un potente influjo nacionalista. «Después de la Cruzada, el renacimiento del catolicismo [más bien diríamos, del proyecto de recatolización] también convirtió al Barroco en un componente clave dentro de los ritos de victoria» (Vincent 2017, 96).

66 «todo esto cuando disminuía la asistencia a la misa, la recepción de los últimos sacramentos, las vocaciones sacerdotales» (Ruiz Vergara 1980).
Madre de la Iglesia (1968), Nuestra Señora de Belén (1968), Nuestra Señora del Carmen (1971), Nuestra Señora del Pilar (1971), San Francisco de Asís (1971), San Pablo Apóstol (1971) y Santa Teresa de Jesús (1971). ${ }^{67}$ Todas se instituyeron en barrios obreros surgidos en esos años al socaire del éxodo rural producido por la industrialización de la ciudad. Cinco de las nueve se ubicaron en locales de planta baja y todas compartían una estética muy en sintonía con las nuevas bases del concilio, con paredes encaladas, vacías de ornamentación, con un crucifijo presidiendo el presbiterio, con los elementos litúrgicos básicos para la celebración de la misa y con puertas de reducido tamaño, todo ello expresión de una (nueva) Iglesia de apariencia pobre y más entregada a los pobres, y sin la mínima intención de que hermandades y cofradías se constituyeran en el seno de esas nuevas parroquias.

Un caso muy significativo de la nueva perspectiva con la que parte de la Iglesia comenzaba a mirar a las cofradías fue el que sufrieron las hermandades de los Mutilados y de San Francisco. Ante la necesidad de reformar y restaurar el convento de San Francisco Javier, la primera abandonó la iglesia en 1960, estableciéndose de forma permanente en la nueva parroquia de San Sebastián. La segunda lo hizo de manera forzosa en diciembre de 1963, trasladándose de forma provisional a la catedral, ya que la intención de la corporación era regresar al convento una vez acabadas las obras. Pero los padres jesuitas que regentaban el templo de San Francisco Javier tenían otras intenciones. Derribaron el antiguo convento y construyeron una iglesia nueva con verjas, escalinata y una pequeña puerta, lo que hacía imposible la salida procesional de la cofradía, motivo por el cual jamás pudo regresar.

Los años en la catedral fueron tiempos difíciles para la corporación, con continuas disputas con el cabildo catedralicio, que imponía normas que cambiaban anualmente e instaba a la hermandad a buscar un nuevo templo en el que asentarse. ${ }^{68}$ El punto álgido de esas disputas llegó en 1975, cuando la cofradía tuvo que salir el Miércoles Santo desde la ruinosa ermita de la Soledad al no aceptar las condiciones impuestas por la autoridad eclesiástica. En la Semana Santa de 1977 se vio obligada a realizar su estación de penitencia en la tarde del Martes Santo por orden del cabildo. ${ }^{69}$ En octubre de 1976, la autoridad eclesiástica había instado a la cofradía a abandonar de forma definitiva el templo, aconsejándole trasladar sus imágenes bien a su antigua sede - desde la que se hacía imposible la salida - o bien a alguna de las nuevas iglesias construidas en los modernos barrios obreros de la ciudad. ${ }^{70}$ Finalmente, la cofradía decidió iniciar

67 Las fechas de fundación de las parroquias de Huelva capital pueden consultarse en la propia página oficial de la diócesis de Huelva: http://www.diocesisdehuelva.es/guia-diocesana/parroquias/.

68 Las primeras tensiones entre la cofradía y el cabildo catedral vienen reflejadas en varios escritos fechados el 16 de octubre de 1963, el 19 de febrero de 1964, el 21 de febrero de 1964 y el 27 de marzo de 1964. Sitos en la carpeta 1323 del Fondo Díaz Hierro del Archivo Municipal de Huelva.

69 Odiel, 5 de abril de 1977, 25. Durante años, el cabildo le había propuesto la opción de trasladar su día de salida al Martes Santo mientras saliera de la iglesia catedral de la Merced, alegando la necesidad de que los pasos estuvieran fuera del templo en la mañana del Jueves Santo para la celebración de los oficios, algo que rechazó sistemáticamente la junta de gobierno.

70 Misiva del cabildo catedral a la hermandad de San Francisco, fechada el 8 de octubre de 1976. Hallada en la carpeta 1323 del Fondo Díaz Hierro del Archivo Municipal de Huelva. 
la construcción de una capilla propia y abandonó el templo catedralicio tras su salida procesional en la Semana Santa de $1978 .^{71}$

Ciertamente, hubo algunos sacerdotes que durante estos años de crisis y tensión abogaron por la posición de las hermandades en la Iglesia y su importancia de cara a un pueblo que iba inmiscuyéndose en los caminos de la secularización. ${ }^{72}$ Así lo reconocía el canónigo Luis Pardo Gil, considerado baluarte de las cofradías entre el clero onubense:

Las cofradías no sólo tienen razón de ser actualmente, sino que el día que desaparecieran, si esto llegara, que no creo que llegue, la fe del pueblo daría un paso atrás de tales proporciones, difíciles de prever en sus consecuencias, para caer en el siglo XX en lo mismo de que se libró en el siglo XVI: en la herejía luterana con todas sus secuelas. ${ }^{73}$

Pero el padre Luis Pardo pertenecía a esa generación del clero integrista y preconciliar que las había amparado y fomentado en los años del primer franquismo, generación que ya era minoritaria en el seno de la Iglesia diocesana de Huelva. La desaparición del resto de curas partidarios de las posiciones preconciliares y del sostenimiento y legitimación del nacionalcatolicismo era una realidad palpable $y$, casi como únicos exponentes, quedaban Luis Pardo y José Muñoz. ${ }^{74}$

La asamblea conjunta de obispos y sacerdotes que se celebró en septiembre de 1971 supuso el cenit de la movilización del movimiento progresista del clero -en buena medida rupturista con el régimen-, que tuvo su mayor crecimiento entre 1968 y 1971 . En la misma, se produjeron significativos altercados entre el clero integrista y el clero aperturista, es decir, entre los representantes de las dos culturas políticas católicas intraeclesiales hegemónicas. ${ }^{75} \mathrm{En}$ ella, a pesar de los intentos de boicot por parte de algunos prelados adictos al régimen, la jerarquía eclesiástica pidió perdón por no haber actuado durante las décadas anteriores como instrumento de reconciliación; se arrepintió no sólo de su posición durante la Guerra Civil sino también de haber actuado como familia política del régimen, anhelando convertirse en la institución de todos y no únicamente de los vencedores. ${ }^{76}$

71 Odiel, 23 de marzo de 1978, 19.

72 «los sacerdotes conservadores consideraban que la secularización era un proceso social negativo, que identificaban con la descristianización y la pérdida de influencia de la religión y la Iglesia» (Moreno Seco 2008, 146).

73 Odiel, 9 de marzo de 1970. Recorte hallado en la carpeta 1057 del Fondo Díaz Hierro del Archivo Municipal de Huelva.

${ }^{74}$ En esos años de principios de los setenta, el padre José Muñoz Blanco iría recibiendo diversos reconocimientos públicos que serían resaltados por la prensa local del Movimiento. Por ejemplo, en diciembre de 1971, con motivo de sus bodas de oro con la vida sacerdotal, fue nombrado Caballero de la Orden de Alfonso X 'el Sabio'. Odiel, 24 de diciembre de 1971, 12.

75 Era natural la tensión y crispación generada en el ala integrista, ya que, en palabras de Raguer Suñer 1998, 40, «se le hundía no sólo su teología y su noción del catolicismo sino también su idea de España».

76 Montero García 2011, 54 señala que la asamblea conjunta del clero y los obispos representa el punto culminante de la tensión intraeclesial española. A partir de ese momento, se expresa con más rotundidad la división entre el clero partidario del «despegue» del franquismo y el grupo resistente y reaccionario. Es decir, supone «el acontecimiento que marca tanto el «despegue» de la Iglesia, en su
En las elecciones de la Conferencia Episcopal de marzo de 1972 se concretó el triunfo de la corriente aperturista y, dentro de ella, de la línea posibilista sobre la rupturista. Con ello, se comenzaba a cavar la tumba de la «Carta colectiva del Episcopado español al mundo» de julio de 1937, que sería sepultada el 23 de enero de 1973 con la aparición del renovador documento "La Iglesia y la Comunidad Política». Con este documento, la jerarquía de la Iglesia española retiraba su amparo y bendición a la política de la dictadura y abandonaba el papel de legitimadora de la verdad ideológico-política, desmarcándose de esa Iglesia de la Cruzada que tan fielmente sirvió a Franco. Los cuatro aspectos fundamentales que poseía "La Iglesia y la Comunidad Política» eran: la defensa de la pluralidad de opciones políticas que podían brotar legítimamente de la fe; el compromiso de los cristianos con la justicia; la denuncia profética como acto misional de la Iglesia; y, en último lugar, la mutua independencia y sana colaboración entre el Estado y la Iglesia al servicio de los hombres. ${ }^{77}$

A partir de entonces se establecieron unas tensas relaciones institucionales entre la Conferencia Episcopal y el gobierno. La primera exigía que las nuevas bases proyectadas en "La Iglesia y la Comunidad Política» primaran sobre el pasado de unión Iglesia-Estado, salvaguardando la independencia y libertad de la institución católica con respecto al régimen. Pero la dictadura no cedió a la presión eclesiástica, abriéndose una profunda brecha entre el Estado franquista y la Iglesia que desembocó en multitud de conflictos expresados de diferentes de maneras, predominando las simbólicas.

En la diócesis de Huelva, la expresión de esa tensión sería notoria, pues la mayoría de los párrocos onubenses ya no rogaban en las misas por Franco, sino que lo hacían «por todos los que rigen los destinos de los pueblos». ${ }^{78}$ En estos años del tardofranquismo, en la prensa local del Movimiento solían aparecer artículos de opinión de elementos pertenecientes a los sectores católicos más cercanos y partidarios del régimen denunciando que ningún cura nombraba ya en sus peticiones al Generalísimo. Uno de 1974 se quejaba de que sólo el sacerdote José Muñoz acostumbraba a pedir por «nuestro Santo Padre el Papa, nuestro Obispo Rafael, por nuestro jefe de Estado Francisco, por el pueblo y por el Ejército», como antaño hacían todos:

En Huelva hay un sacerdote que en su misa, jamás olvida de pedir públicamente y en voz muy alta por nuestro Jefe de Estado [...], y es que a este sacerdote le brota el agradecimiento por todos los poros de su cuerpo y no puede olvidar nunca, los horrores vividos los últimos días del mes de julio del 1936 hasta la entrada de nuestro Glorioso Ejército en Huelva. Este sacerdote es don José Muñoz que en la misa que todos los domingos celebra en el Santuario de Nuestra Señora de la Cinta, a las 9,30 nos hace humedecer los ojos. ${ }^{79}$

conjunto, respecto del Régimen, como la radicalización de la división interna del clero y el catolicismo español» (Montero García 2011, 56). Moreno Seco 2008, 164, por su parte, señala que, desde «una perspectiva antropológica, se ha dicho que la Asamblea conjunta significó un mecanismo de ritualización del conflicto, es decir, lo hizo visible».

77 Véase Martín de Santa Olalla 2005.

78 «Pidamos por el Caudillo», Odiel, 17 de octubre de 1974, 10.

79 «Pidamos por el Caudillo», Odiel, 17 de octubre de 1974, 10. Firmado por una «española agradecida y admiradora de nuestro Caudillo». 
Otro artículo de prensa de 1975 también se quejaba de que los curas aperturistas no elevasen «su más ferviente oración por ese católico agonizante que ha consagrado su vida al servicio de España», lo cual dejaba a las claras la fase de "tirantez que hay entre la Iglesia y el Estado». ${ }^{80} \mathrm{Y}$ mientras avanzaba la guerra fría entre el gobierno y la corriente aperturista del clero, también seguía avanzando la indiferencia de esos sacerdotes hacia las cofradías y la Semana Santa. Desde el mundo de las hermandades salían voces que se quejaban amargamente de las diferencias existentes entre gran parte de la curia y las juntas de gobierno: "Hace falta que de verdad nos den directores espirituales y que éstos nos orienten. ¡Y nos comprendan! Que no somos simplemente personas que quince días antes de la Semana Mayor llenan la iglesia de trastos. iSomos algo más!». ${ }^{81}$

También emanaban posibles soluciones. Directivos cofrades que abogaban por recuperar la antigua unión entre el clero y las cofradías para acabar con esa incomprensión y sentimiento de abandono denunciado por éstas:

-A nuestros oídos llegan rumores de una especie de distanciamiento, llamémosle así, entre el clero y las hermandades. ¿Qué hay de cierto en ello?

- Bueno, la verdad es que no hay contactos como debiera y nosotros nos preguntamos: si tanta atención se prestan a los clubs parroquiales ¿por qué no se apoya y orienta a las Hermandades compuestas en gran mayoría también por gente joven y dispuestos a cualquier actividad que se les asigne?

- Hablemos de soluciones entonces.

-Quizá una reunión del clero y las Cofradías para que ambas partes expongan su versión de los problemas. Y además, que el director espiritual de cada una dirija sus asuntos porque es incomprensible que siendo aquéllas una rama más de la Iglesia esté algunas veces huérfana. Creemos que la unión puede acabar con la incomprensión y lograr una mayor gloria de Dios y bien de las almas. ${ }^{82}$

Y no sólo emanaban voces con reproches o con ansias de comunión; también desde las cofradías salían críticas hacia esa Iglesia posconciliar y aperturista que las repudiaba. El hermano mayor de la hermandad del Calvario, Antonio Navarro Vázquez, publicó un artículo de prensa en el que criticaba a esos curas que catalogaban a las hermandades como instituciones desfasadas, aportando interpretaciones a favor del asociacionismo católico procedentes del propio

80 R. de la C., «¿Hasta cuándo..? - ¡Daos la paz! —¿Quién dice eso?», Odiel, 28 de octubre de 1975, 16.

81 Palabras de la entrevista a Luis Morejón y Eduardo Bacedoni, directivos de la cofradía de los Mutilados. Publicada en Odiel, 6 de abril de 1973. Hallada como recorte de prensa en la carpeta 1058 del Fondo Díaz Hierro del Archivo Municipal de Huelva.

82 Fragmento de la entrevista realizada a Manuel Villegas y Antonio Prieto, mayordomo y secretario - respectivamente- de la hermandad de los Estudiantes. Odiel, 4 de abril de 1973, 13. Los "clubs parroquiales» a los que se referían los directivos de la cofradía de los Estudiantes eran grupos de jóvenes que se reunían en forma de club juvenil adscrito a una parroquia, colaboraban con ella en asuntos asistenciales y le daban "vida» a la misma. Hacían las funciones de espacios de sociabilidad juvenil parroquial, poseían espacios lúdicos propios en un lugar cercano a la parroquia y eran dirigidos espiritualmente por el párroco. Suponían una puerta de entrada de los laicos a la renovada vida de la Iglesia, cuestión en la que había incidido el vaticano II.
Vaticano II y señalando a los jóvenes de Huelva como los nuevos actores encargados de revitalizar la Semana Santa. ${ }^{83}$

Sin embargo, la mayoría del clero renovador y aperturista seguía y seguiría a lo suyo. Pretendía una adaptación de la Iglesia a los principios de la modernidad; anhelaba y buscaba una fe individual basada en la razón y el compromiso y no una religiosidad epidérmica, impulsiva, sentimental y colectiva, centrada en la iconolatría, cuyas prácticas y rituales públicos se imbricaban con significados identitarios y políticos de los que pretendía alejarse. Así lo expresaba el padre Jesús Domínguez, vicario episcopal de parroquias del arzobispado de Sevilla:

[Lo ideal es una] depuración de lo religioso sin mezclarlo con lo social [...]. El pueblo es religioso. Pero para mí, entre lo religioso y lo cristiano hay un abismo. Nuestro pueblo es muy religioso, pero muy poco cristiano. Sin embargo, tiene una apariencia de cristiano porque en sus comportamientos religiosos utiliza los signos cristianos. [...] Sólo hay un camino: la personalización de la fe. Que la gente descubra la fe no por una influencia de tipo social o imposición del medio ambiente, sino que haga un descubrimiento personal de su fe. Este es el camino que sigue la Iglesia hoy para superar esa socialización, en el buen sentido, de lo religioso, como si lo religioso formara parte de la vida social. [...] La lucha de la Iglesia hoy, no es que no quiera que la gente vaya masivamente a la fe. Lo que no quiere es que vayan sin una aceptación personal. ${ }^{84}$

Al igual que el clero renovador, entre principio y mediados de los setenta, gran parte de la población de Huelva también había abandonado el interés en la Semana Santa, las cofradías y otras prácticas de religiosidad popular. Escasos cortejos de nazarenos y reducidas filas de público compusieron el paisaje de las procesiones de la mayoría de las cofradías onubenses en los últimos años del franquismo. Apenas un par de hileras de personas contemplaban los desfiles cofradieros en estos años - a excepción de las procesiones de las hermandades con las imágenes más tradicionales y populares-, realidad que era señalada constantemente en la prensa ${ }^{85}$ y retratada en las fotografías que hemos rescatado de diversos archivos. Como rememoraba uno de nuestros informantes:

Hombre, la Semana Santa de mi infancia verás... [...] yo recuerdo que era una Semana Santa triste, muy triste, con muy poca gente en la calle. La gente era prácticamente una hilerita de gente viendo pasar la procesión. Era poco participativa y muy rígida. Yo veía aquello muy rígido. Entonces yo no... A mí aquella Semana Santa no me llamaba la atención. [...] la recuerdo muy triste, con poca participación, rígida y no... ${ }^{86}$

83 «¿Están en desfase las hermandades y cofradías?», Odiel, 23 de marzo de 1975, 12.

84 Odiel, 30 de enero de 1975, 13.

85 «está visto que la gente no quiere cooperar. Comprendemos que a todos no va a gustar la Semana Mayor; y que habrá quien esté decididamente en contra porque la considere anacrónica. Pero no es lógico, ni en un caso ni otro, que se entorpezca el desfile». Odiel, 9 de abril de 1974, 12.

86 D. A. P., antiguo costalero de diversas cofradías, 61 años. 
Las causas eran varias, complejas y de diversa naturaleza. ${ }^{87}$ La transformación demográfica, el cambio social e ideológico, el auge del consumismo y de las nuevas modas, espectáculos y rituales modernos, unido a una identificación de la fiesta como un tipo de manifestación ritual pro-régimen y al rechazo del clero posconciliar, debilitaron y erosionaron con fuerza la Semana Santa onubense. La industrialización de la ciudad, con la instalación del polo químico y de desarrollo en 1964, hizo que, en años sucesivos, el nivel de vida aumentara considerablemente y que el consumo/consumismo y los retiros al campo y las playas se dispararan como nuevos rituales contemporáneos en los días de descanso y de ocio. ${ }^{88}$ La industrialización había propiciado un éxodo rural masivo hacia la capital onubense; en torno a la mitad de la población procedía de otros lugares y, en muchos casos, volvía a ellos en días de fiesta y no se identificaba con las tradicionales costumbres locales. ${ }^{89}$ La nueva situación de medio-clasismo in crescendo favorecía tanto la secularización como la deslegitimación de las estructuras políticas autoritarias y la preferencia por formas de gobierno democráticas y liberales. La excesiva asimilación de la fiesta a los valores e intereses del régimen y la desvinculación e incapacidad de las cofradías para articular nuevas significaciones identitarias con las comunidades territoriales - barrios - en las que estaban insertas también fueron motivo de su pérdida de importancia en la generación de nuevas identidades colectivas a nivel local.

\section{CONCLUSIONES}

En conclusión, como hemos analizado, la tensión generada entre las dos culturas políticas católicas - representantes de las dos corrientes ideológicas eclesiásticas hegemónicas-, la imposición de la aperturista en las esferas de poder político de la Iglesia católica española y los

87 Para Ruiz Andrés 2017, 214, «la secularización que se inicia entre los sesenta y los setenta tiene unas características [...] que nos sitúan más bien en el marco de cambios masivos ligados al consumo/ consumismo y que responde primordialmente a la esencial relación entre sociedad y religiosidad, fundamental para complementar la más citada relación Estado-Iglesia».

88 En este sentido, Ruiz García 2001 ha señalado que el hecho de poseer una segunda vivienda en alguno de los municipios costeros de la provincia de Huelva respondía a una pauta sociocultural del modo de vida de la incipiente clase media onubense del momento, que buscaba, en los cercanos pueblos de la costa o en sus pueblos de origen, su particular lugar de retiro. Muchos de los técnicos cualificados que llegaron a Huelva hicieron suyo este tipo de forma de vida.

89 Según datos del INE, Huelva contaba con una población de 74.823 personas en 1960. En el año 1981, los datos arrojaban un incremento de 52.999 habitantes, siendo la cifra total de 127.822 . Señala Monteagudo López-Menchero 1984 que, según los datos del Padrón Municipal de 1981 , el $41,7 \%$ de los habitantes no había nacido en la capital y el $52,8 \%$ de ellos procedía de la provincia, principalmente de las comarcas más deprimidas de la misma. El $43 \%$ del resto de emigrantes llegados a la ciudad procedían de otras provincias españolas, especialmente de Sevilla y Badajoz, y el 4,2\% restante procedía del extranjero. Muchas de las personas que migraron desde sus pueblos hasta la capital mantuvieron residencias familiares en el ámbito rural, a las que solían ir en días de descanso y fiestas, conservando también allí sus devociones, sus celebraciones festivas, sus símbolos de identificación colectivos y la mayoría de sus relaciones sociales y de parentesco. En definitiva, gran parte de los elementos que conformaban su propia identidad. conflictos que se sucedieron entre ésta y los poderes franquistas, se visibilizaron en el espacio socio-simbólico que era la Semana Santa en tanto manifestación de religiosidad popular que aunaba la representación de las élites y los sectores populares. La potente vinculación y apropiación que las tradiciones políticas reaccionarias y conservadoras y la integrista jerarquía católica preconciliar habían establecido con la Semana Santa desde los comienzos del régimen, derivaron en un rechazo de la misma por parte del clero aperturista y de gran parte de la población local, fruto también de la imbricación con otros complejos factores ideológicos, económicos y sociológicos. Éstos se correspondían con la interpretación sobre la nueva religiosidad que pregonaba el Vaticano II, la liberalización económica, la modernización, la secularización y las transformaciones demográficas y sociológicas fruto de la industrialización.

A pesar de la degradación de popularidad que sufrió la Semana Santa en los sesenta y setenta, los poderes políticos franquistas locales y los cada vez menos elementos del clero integrista diocesano continuaron expresando, a través de las procesiones, la legitimidad del régimen como salvador y garante de estos actos rituales tradicionales que vinculaban a la identidad nacional consustancialmente católica. Para ello, no les importó sustentarla económicamente ni seguir utilizándola como plataforma de exhibición con claros matices políticos. Sin embargo, el clero aperturista posconciliar combatió esas narrativas, repudió a las cofradías y su ceremonial y comenzó un proyecto para desmontar la tesis que unía el catolicismo al españolismo pregonado por el régimen, abriéndose a nuevas sensibilidades políticas e ideológicas que consideraba legítimas. Se acercó a nuevos grupos eclesiales seglares que vivían su fe desde los patrones de la centralidad de una liturgia no ampulosa y la entrega a la construcción social del mundo, nuevos patrones de la lógica conciliar, rechazando esas manifestaciones de religiosidad popular que imbricaban significaciones políticas e identitarias - que entendía como paganas - de las que pretendía desvincularse.

En medio de esa tensión entre el poder político y el religioso, que contribuiría a terminar de deslegitimar social y simbólicamente la dictadura, fallecía Franco y se dieron los últimos coletazos de un régimen que se había sustentado durante casi cuarenta años en el poder, fruto de la coalición entre tradiciones políticas cuya simbiosis y relación se había erosionado fuertemente. Al igual que la Iglesia, algunas de esas tradiciones políticas, como el monarquismo y algunos elementos de FET, comenzaron a inmiscuirse en los caminos del reformismo y aperturismo hacia un nuevo régimen político, descosiendo los mecanismos simbólicos que habían posibilitado y protagonizado la construcción de una cultura política franquista.

\section{BiBLIOGRAFÍA}

Baisotti, Pablo Alberto. 2017. "La construcción simbólica del liderazgo providencial del "caudillo" a través de la prensa católica y falangista (1936-1942)». Hispania Sacra 69, 140: 709-720. https:// doi.org/10.3989/hs.2017.044

Barreiro López, Paula. 2014. «Reinterpreting the Past. The Baroque Phantom during Francoism». Bulletin of Spanish Studies 91 (5): 715-734. https://doi.org/10.1080/14753820.2014.908566 
Box Varela, Zira. 2008. La fundación de un régimen. La construcción simbólica del franquismo. Tesis Doctoral. Universidad Complutense de Madrid.

Burke, Peter. 2006. ¿Qué es la historia cultural? Barcelona: Paidós.

Carrasco Terriza, Manuel Jesús. 2002. «La diócesis de Huelva (19531993)». En Historia de las diócesis españolas. Iglesias de Sevilla, Huelva, Jerez y Cádiz y Ceuta, coord. José Sánchez Herrero, vol. 10 533-568. Madrid: Biblioteca de Autores Cristianos.

Casanova Ruiz, Julián. 2005. La Iglesia de Franco. Barcelona: Crítica.

Casanova Ruiz, Julián y Carlos Gil Andrés. 2009. Historia de España en el siglo XX. Barcelona: Ariel.

de la Cueva Merino, Julio. 1998. «El anticlericalismo en la Segunda República y la Guerra Civil». En El anticlericalismo español contemporáneo, ed. Emilio La Parra López y Manuel Suárez Cortina, 211301. Madrid: Biblioteca Nueva.

Delgado Ruiz, Manuel. 1993. "La "religiosidad popular". En torno a un falso problema». Gazeta de Antropología 10.

Delgado Ruiz, Manuel. 2001. Luces iconoclastas. Anticlericalismo, espacio y ritual en la España contemporánea. Barcelona: Ariel.

Delgado Ruiz, Manuel. 2005. «Violencia anticlerical e iconoclasta en la España contemporánea». En Culturas y políticas de la violencia. España siglo XX, coord. José Luis Ledesma Vera, Javier Muñoz Soro y Javier Rodrigo, 75-100. Madrid: Siete Mares.

Di Febo, Giuliana. 1988. La santa de la raza. Un culto barroco en la España franquista. Barcelona: Icaria.

Domene Verdú, José Fernando. 2017. «La función social e ideológica de las fiestas religiosas: identidad local, control social e instrumento de dominación». Revista de Dialectología y Tradiciones Populares 72 (1): 171-197. https://doi.org/10.3989/rdtp.2017.01.007

Espinosa Maestre, Francisco. 2005. La Guerra Civil en Huelva. Huelva: Diputación Provincial de Huelva.

Feria Vázquez, Pedro. 2009. Los protagonistas del cambio político. Transición a la democracia en la ciudad de Huelva (1964-1980). Huelva: Diputación Provincial de Huelva.

Hernández Burgos, Claudio. 2011. Granada Azul. La construcción de la "Cultura de la Victoria" en el primer franquismo. Granada: Comares.

Hernández Sotelo, Anel. 2010. «Reseña de «¿Qué es la historia cultural?» de Peter Burke». Fronteras de la Historia 15 (2): 417-421.

Hobsbawm, Eric. 2002. «Introducción: La invención de la tradición». En La invención de la tradición, ed. Eric Hobsbawm y Terence Ranger, 7-21. Barcelona: Crítica.

Hurtado Sánchez, José. 2000. Cofradías y poderes. Relaciones y conflictos. Sevilla, 1939-1999. Sevilla: Editorial Castillejo.

Langa Nuño, Concha. 2014. “"De Sevilla la roja a la Tierra de María Santísima": la "recatolización" de Sevilla». En La Iglesia en Andalucía durante la Guerra Civil y el primer franquismo, coord. José Leonardo Ruiz Sánchez, 15-47. Sevilla: Universidad de Sevilla.

Mancha Castro, José Carlos. 2017. «Cofradías y poderes políticos. Una aproximación a las hermandades de Semana Santa en la Huelva del primer franquismo». Revista Andaluza de Antropología 13: 140-163. http://doi.org/10.12795/RAA.2017.13.06

Mancha Castro, José Carlos. 2018. «La Semana Santa y la recatolización de Huelva. Un acercamiento a la construcción simbólica del franquismo de posguerra». Pasado y Memoria. Revista de Historia Contemporánea 17: 413-452. https://doi.org/10.14198/PASADO2018.17.15

Mancha Castro, José Carlos. 2020. La Semana Santa y la construcción simbólica del franquismo en Huelva (1937-1961). Sevilla: Universidad Internacional de Andalucía.

Martín de Santa Olalla, Pablo. 2005. La Iglesia que se enfrentó a Franco: Pablo VI, la Conferencia Episcopal y el Concordato de 1953. Madrid: Dilex.

Mauss, Marcel. 2009. Ensayo sobre el Don. Forma y función del intercambio en las sociedades arcaicas. Madrid: Katz Editores.

Monteagudo López-Menchero, Jesús. 1984. «La ciudad de Huelva: resultado demográfico de la polarización industrial y la despoblación rural». En Actas del III Coloquio Ibérico de Geografía, 350-364. Barcelona: Universidad de Barcelona.
Montero García, Feliciano. 2009. La Iglesia: de la colaboración a la disidencia (1956-1975). Madrid: Encuentro.

Montero García, Feliciano. 2011. «La Iglesia dividida. Tensiones intraeclesiales en el segundo franquismo. (La crisis postconciliar en el contexto del tardofranquismo)». En De la cruzada al desenganche: la Iglesia española entre el franquismo y la transición, coord. Manuel Ortiz Heras y Damián A. González, 51-76. Madrid: Sílex.

Moreno Navarro, Isidoro. 1997. La antigua hermandad de los negros de Sevilla: etnicidad, poder y sociedad en 600 años de historia. Sevilla: Universidad de Sevilla.

Moreno Navarro, Isidoro. 1999. Las Hermandades andaluzas: una aproximación desde la Antropología. Sevilla: Universidad de Sevilla.

Moreno Navarro, Isidoro. 2006. La Semana Santa de Sevilla. Conformación, mixtificación y significaciones. Sevilla: Biblioteca de Temas Sevillanos.

Moreno Seco, Mónica. 2002. «Creencias religiosas y política en la dictadura franquista». Pasado y Memoria. Revista de Historia Contemporánea 1: 235-283.

Moreno Seco, Mónica. 2008. «El clero ante los cambios sociales y culturales de los años 60». En Eppure si muove: La percepción de los cambios en España (1959-1976), coord. Glicerio Sánchez Recio, 145-168. Madrid: Biblioteca Nueva.

Moreno Seco, Mónica. 2011. «Mujeres en la Acción Católica y el Opus Dei. Identidades de género y culturas políticas en el catolicismo de los años sesenta». Historia y Política. Ideas, procesos y movimientos sociales 28: 167-194.

Navarro de la Fuente, Santiago. 2014. «La religiosidad popular como elemento de adhesión al primer franquismo. Una aproximación al caso de Sevilla». En La Iglesia en Andalucía durante la Guerra Civil y el primer franquismo, coord. José Leonardo Ruiz Sánchez, 109126. Sevilla: Universidad de Sevilla.

Raguer Suñer, Hilari. 1998. "El Concilio Vaticano II y la España de Franco». Historia y vida 362: 34-49.

Richards, Michael. 2010. «Presentando armas al Santísimo Sacramento: Guerra Civil y Semana Santa en la ciudad de Málaga, 1936-1939». En España fragmentada. Historia cultural y Guerra Civil española, ed. Chris Ealham y Michael Richards, 253-286. Granada: Comares.

Rina Simón, César. 2015. "La construcción de los imaginarios franquistas y la religiosidad "popular", 1931-1945». Pasado y Memoria. Revista de Historia Contemporánea 14: 179-196. https://doi.org/10.14198/PASADO2015.14.07

Rina Simón, César. 2016. "Rituales de pasión, muerte y resurrección. La religiosidad popular y la legitimidad sagrada del franquismo». En Fascismo y modernismo: política y cultura en la Europa entreguerras (1918-1945), ed. Francisco Cobo Romero, Claudio Hernández Burgos y Miguel Ángel del Arco Blanco, 171-184. Granada: Comares.

Rina Simón, César. 2017. «Fascismo, nacionalcatolicismo y religiosidad popular. Combates por la significación de la dictadura (19361940)». Historia y Política. Ideas, procesos y movimientos sociales 37: 241-266. https://doi.org/10.18042/hp.37.09

Rodríguez Becerra, Salvador. 1985. Las fiestas de Andalucía. Sevilla: Editoriales Andaluzas Unidas.

Rodríguez Becerra, Salvador. 2011. «Nuevas perspectivas sobre la religiosidad popular o religión común de los andaluces». Revista Murciana de Antropología 18: 31-41.

Ruiz Andrés, Rafael. 2017. «El proceso de secularización de la sociedad española (1960-2010): entre la historia y la memoria». Pasado y Memoria. Revista de Historia Contemporánea 16: 207-232. https://doi.org/10.14198/PASADO2017.16.09

Ruiz García, Marta. 2001. "La inmigración industrial en Huelva: procesos de integración de los trabajadores del Polo Industrial». Trabajo: revista andaluza de relaciones laborales 10: 159-177.

Ruiz Vergara, Fernando. 1980. Rocío. España: Tangana Films. Documental.

Saz Campos, Ismael. 2003. España contra España. Los nacionalismos franquistas. Madrid: Marcial Pons. 
Sugrañes Gómez, Eduardo J. 2000. Almohadilla y costal. Capataces y costaleros en Huelva, de profesión a devoción. Huelva: Fundación El Monte.

Tello Camacho, Manuel. 1993. Medio siglo de historia de la hermandad de Nuestro Padre Jesús de las Penas en sus Tres Caídas y María Santísima del Amor. 1944-1994. Huelva: Hermandad de las Tres Caídas.

Thomàs Andreu, Joan Maria. 2001. La Falange de Franco. Fascismo y fascistización en el régimen franquista: (1937-1945). Barcelona: Plaza y Janés.
Thomàs Andreu, Joan Maria. 2016. Franquistas contra franquistas. Luchas por el poder en la cúpula del régimen de Franco. Barcelona: Debate.

Vincent, Mary. 2017. "La Semana Santa en el nacionalcatolicismo: espacio urbano, arte e historia. El caso de Valladolid (1939-1949)». Historia y Política. Ideas, procesos y movimientos sociales 38: 91-127. https://doi.org/10.18042/hp.38.04 